\title{
Effect of fluid additives on rock drilling
}

\author{
Rawal Rohit, NC Karmakar and SK Sharma \\ Indian Institute of Technology (BHU) \\ Varanasi, India \\ rohitr.rs.min15@itbhu.ac.in
}

\begin{abstract}
Drilling is a very dominant operation in all rock cutting industries, namely, mining, petroleum, natural gas and civil engineering. The objective of this study is to understand the behaviour of rock drillability by mean of penetration rate of bit, with concentration of $10 \mathrm{ppm}$ of carboxymethyl cellulose, guar gum, polyacrylamide polymer additives to drilling fluid. A total of four different type of drilling fluids were used to compare and identify the best drilling fluid for chunar sandstone.
\end{abstract}

For this research work, a laboratory drill setup was fabricated to study the effect of various rotary drilling machine parameters on overall drilling performance. Outcome of the experiment is discussed in terms of rate of penetration. It was found that at $10 \mathrm{ppm}$ concentration, the performance of guar gum and carboxymethyl cellulose is almost same and much better then that of polyacrylamide.

Keywords-Drilling fluids; drillability; penetration rate; water soluble polymer

\section{INTRODUCTION}

Drilling is the first unit operation of mining engineering that provides knowledge about sub-surface strata. Further, this comprises as a major activity in mining engineering, petroleum engineering, $\mathrm{CO} 2$ storage, natural gas extraction, tunneling and many other engineering activities. Due to improper flushing, the debris generated may not be removed properly from hole, which may cause regrinding of debris and jamming of drill bit. This leads to loss of time and energy.

Proper selection of flushing media may help in plugging the fractures, provide better bit rock interaction and lead to better drilling performance. Water soluble polymer possesses many good qualities for improving drilling performance, namely reducing friction, cooling of drill bits, hence causing uniform wear of the drill bit etc.

In this research, commonly available polymers such as guar gum (GG), carboxymethyle cellulose (CMC), and polyacrylamide (PAM) were used [1, 3, 11, 6, 9].

\section{MATERIALS AND Methodology}

Various materials and measurement procedure that were used during this study are discussed as follows.

\section{A. Rock sample}

Fine grain chunar sandstone samples were used to find out the effect of various drilling fluid on drillability of rock.

\section{B. Drilling Fluid}

In this work four types of drilling fluids were used to measure the drillability. Water alone was used as a drilling fluid and three other fluids were prepared as $10 \mathrm{ppm}$ solution of three water soluble polymers, namely, guar gum (GG), carboxymethyl cellulose (CMC) and polyacrylamide (PAM) in distilled water individually.

\section{Laboratory Rock Drilling Setup}

Drilling setup was fabricated for laboratory examination of various machine and rock parameters of rock drillability. Rock drillability is defined as "the penetration rate of a drill bit into the rock" [8]. It depends on combined effect of rock and machine parameters. Machine parameters includes load on bit, torque, rotational speed of bit and flushing media [2].

The fabricated setup is capable of providing variation in bit type, bit rotational speed, weight on bit, flushing media, rock sample size with flexibility. This setup also allows us to measure values of depth and diameter of hole, drilling time and power consumption. Each test has been repeated three times to minimize and checkout the error. The holes were drilled with diamond impregnated core bit.

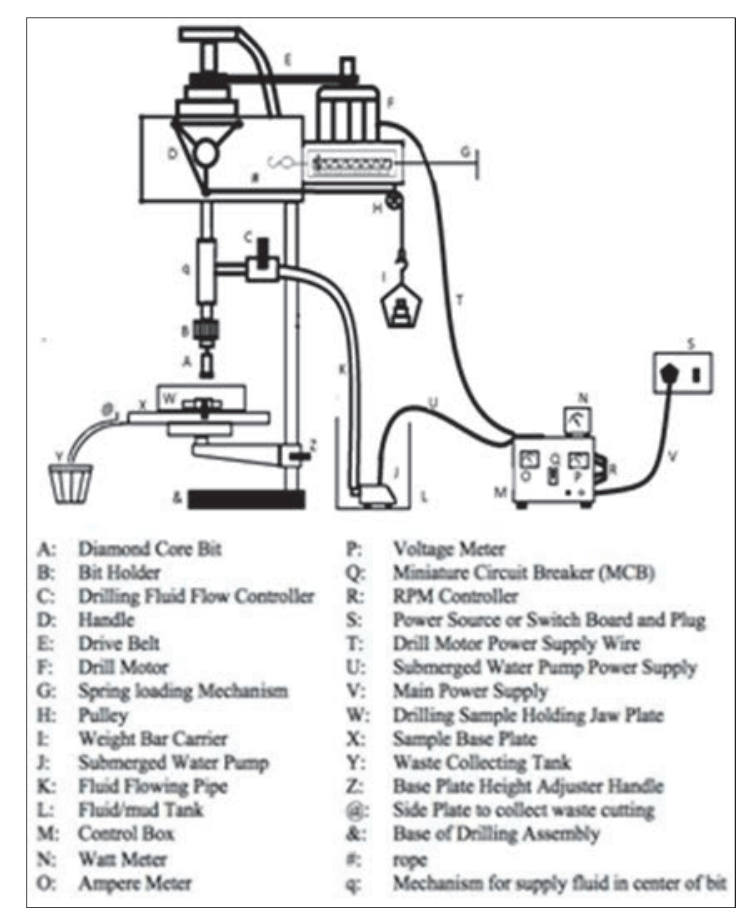

Fig.1. Fabricated setup and description of tagged parts 
Line diagram of fabricated setup and description of tagged parts are shown in Figure 1.

D. Operating Parameters

Table-1 gives the operating parameters used during the experimentation.

TABLE I OPERATING PARAMETER

\begin{tabular}{|c|c|c|c|c|}
\hline $\begin{array}{c}\text { Bit } \\
\text { Rotational } \\
\text { Speed } \\
\text { (RPM) } \\
\end{array}$ & $\begin{array}{c}\text { Weig } \\
\text { ht on } \\
\text { Bit } \\
(\mathbf{K g}) \\
\end{array}$ & $\begin{array}{l}\text { Rock } \\
\text { Type }\end{array}$ & $\begin{array}{l}\text { Flushing } \\
\text { Media }\end{array}$ & $\begin{array}{c}\text { Polymer } \\
\text { Additives (10 } \\
\text { ppm) }\end{array}$ \\
\hline 450 & 1 & \multirow{3}{*}{$\begin{array}{l}\text { Fine } \\
\text { Grain } \\
\text { Sands } \\
\text { tone }\end{array}$} & $\begin{array}{c}\text { Tap Water } \\
\text { Alone }\end{array}$ & Guar Gum \\
\hline 600 & 3 & & \multirow{2}{*}{$\begin{array}{c}\text { Tap Water + } \\
\text { Polymer } \\
\text { Additives }\end{array}$} & $\begin{array}{l}\text { Carboxymethyl } \\
\text { Cellulose }\end{array}$ \\
\hline 750 & 5 & & & Polyacrylamide \\
\hline
\end{tabular}

This value is produced by calculating ratio of "Depth covered by drill bit by cutting rock mass and the time required to drill that mass" as shown in eq. (1). It is expressed in the unit of " $\mathrm{mm} / \mathrm{min}$ ".

$$
\text { Penetration Rate }=\text { Depth of hole }(\mathrm{mm}) / \text { Time }(\mathrm{min})
$$

\section{RESULT AND DISCUSSION}

Final calculated values of penetration rate for all four types of drilling fluid were analyzed and the percentage increment in ROP was calculated by considering tap water as base drilling fluid.

\section{A. Penetration Rate (ROP)}

All the experimental data along with calculated values of penetration rates for all drilling fluids individually were collected in format of table 2.

TABLE II: EXPERIMENTAL DATA FOR PENETRATION RATE

\begin{tabular}{|c|c|c|c|c|c|c|}
\hline \multirow[b]{2}{*}{ 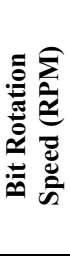 } & \multirow[b]{2}{*}{ 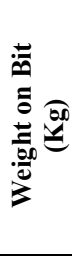 } & \multirow[b]{2}{*}{ 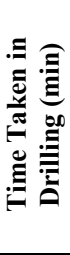 } & \multicolumn{2}{|c|}{$\begin{array}{c}\text { Hole Depth } \\
(\mathrm{mm})\end{array}$} & \multirow{2}{*}{ 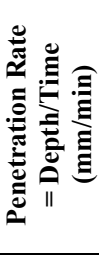 } & \multirow{2}{*}{ 《茪 } \\
\hline & & & \begin{tabular}{|c} 
Meas \\
ured \\
At \\
Three \\
Point \\
s \\
\end{tabular} & $\begin{array}{c}\text { Averag } \\
\text { e } \\
\text { Depth }\end{array}$ & & \\
\hline \multirow{6}{*}{450} & \multirow{3}{*}{1} & \multirow{6}{*}{1} & $\begin{array}{l}4.4 \\
4.3 \\
4.2\end{array}$ & 4.3 & 4.3 & \multirow{3}{*}{4.7} \\
\hline & & & $\begin{array}{l}4.4, \\
4.7 \\
4.5\end{array}$ & 4.53 & 4.53 & \\
\hline & & & $\begin{array}{l}5.2, \\
5.3, \\
5.2\end{array}$ & 5.23 & 5.23 & \\
\hline & \multirow{3}{*}{3} & & $\begin{array}{l}5.6, \\
5.8, \\
5.6\end{array}$ & 5.66 & 5.66 & \multirow{3}{*}{6.0} \\
\hline & & & $\begin{array}{l}6.1, \\
5.2, \\
6.2\end{array}$ & 6.16 & 6.16 & \\
\hline & & & 5.9 & 5.96 & 5.96 & \\
\hline
\end{tabular}

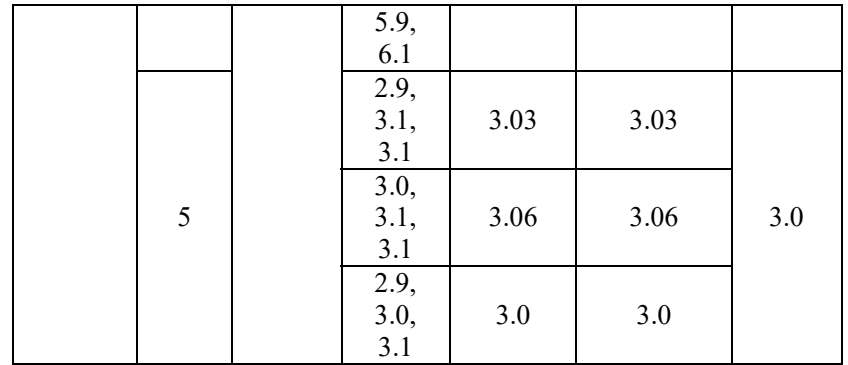

\section{B. Penetration Rate for All Drilling Fluid}

Calculated values of penetration rate for all drilling fluids are tabulated as shown in table 3. This tabulation helps in comparative study of penetration rate. Salient findings have been presented graphically. For best operating condition (maximum penetration rate), each drilling fluid were taken into consideration.

TABle III: Penetration Rate With All Drilling Fluids

\begin{tabular}{|c|c|c|c|c|c|c|}
\hline \multirow{2}{*}{$\begin{array}{c}\text { Bit } \\
\text { Rotati } \\
\text { onal } \\
\text { speed } \\
\text { (rpm) }\end{array}$} & \multirow{2}{*}{$\begin{array}{l}\text { Weigh } \\
\text { t on } \\
\text { Bit } \\
(\mathrm{Kg})\end{array}$} & \multirow{2}{*}{$\begin{array}{c}\text { Time } \\
\text { Taken } \\
\text { in } \\
\text { Drillin } \\
\text { g } \\
(\mathbf{m i n})\end{array}$} & \multicolumn{4}{|c|}{$\begin{array}{l}\text { Avg. Penetration rate } \\
(\mathrm{mm} / \mathrm{min})\end{array}$} \\
\hline & & & $\begin{array}{c}\text { Tap } \\
\text { Water }\end{array}$ & $\begin{array}{c}G G \text { with } \\
\text { water }(10 \\
\text { ppm) }\end{array}$ & $\begin{array}{c}C M C \text { with } \\
\text { water (10 } \\
\text { ppm) }\end{array}$ & $\begin{array}{c}\text { PAM } \\
\text { with } \\
\text { water } \\
(10\end{array}$ \\
\hline \multirow{3}{*}{450} & 1 & \multirow{3}{*}{1} & 4.7 & 10.1 & 7.0 & 6.6 \\
\hline & 3 & & 6.0 & 12.1 & 8.7 & 8.9 \\
\hline & 5 & & 3.0 & 12.5 & 9.2 & 6.6 \\
\hline \multirow{3}{*}{600} & 1 & \multirow{3}{*}{1} & 6.3 & 12.7 & 8.9 & 7.6 \\
\hline & 3 & & 8.1 & 14.3 & 9.4 & 9.6 \\
\hline & 5 & & 10.0 & 15.9 & 11.9 & 13.4 \\
\hline \multirow{3}{*}{750} & 1 & \multirow{3}{*}{1} & 7.5 & 10.9 & 11.4 & 8.5 \\
\hline & 3 & & 8.4 & 14.9 & 16.7 & 12.2 \\
\hline & 5 & & 6.9 & 19.9 & 19.4 & 14.9 \\
\hline
\end{tabular}

\section{PARAMETERS AND CALCULATION}

Outcome of this study was calculated in terms of rate of penetration (ROP).

\section{A. Penetration Rate Measurement}

Rate of drilling is "rate at which bit penetrates the rock". All these best operating values of penetration rates are used to calculate percentage increment in penetration rate, considering the tap water as base drilling fluid. The percentage variation in penetration rate due to $10 \mathrm{ppm}$ concentrations of different fluid polymeric additives are presented through Table 4 and Figure 2. 
TABLE 4: PERCENTAGE INCREMENT IN PENETRATION RATE ON THE BASIS OF TAP WATER AS BASE DRILLING FLUID

\begin{tabular}{|c|c|c|c|}
\hline $\begin{array}{c}\text { Drilling Fluids } \\
\text { (10 ppm con } \\
\text { solution with } \\
\text { water) }\end{array}$ & Guar Gum & $\begin{array}{c}\text { Carboxymethyl } \\
\text { Cellouose }\end{array}$ & Polyacrylamide \\
\hline $\begin{array}{c}\text { Percentage } \\
\text { Increment in } \\
\text { penetration Rate }\end{array}$ & 49.7 & 48.4 & 32.9 \\
\hline
\end{tabular}

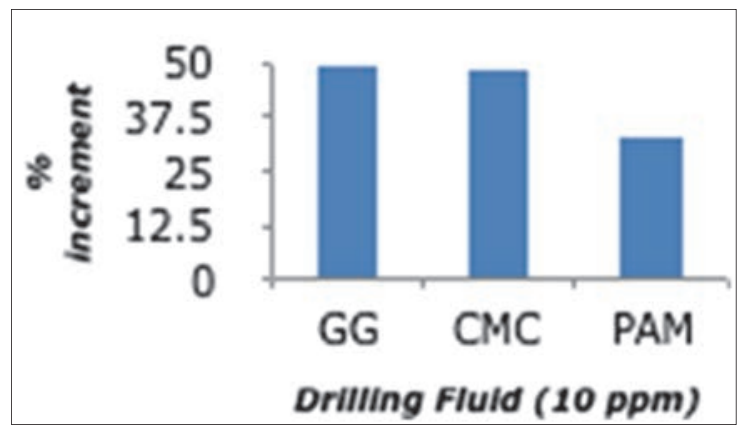

Fig. 2 Percentage increment in Rate of Penetration on the Basis of Tap Water as Base Drilling Fluid

\section{DISCUSSION}

The friction in drilling process (intra-machine friction and drill rod to rock friction) resists the motion of bit, which reduces the drilling performance. All these additives work as a lubricating agent for the annulus space between the drilling rod and the hole.

The viscosity of a lubricant is related to its ability to reduce friction. Viscosity can be defined as fluids internal resistance to flow at specific temperature. The percentage variation in penetration rate due to $10 \mathrm{ppm}$ concentrations of different fluid polymeric additives are presented through Table 4 and Figure 2.

In general, if the lubricant is highly viscous, it will consume a large amount of energy to flow; if it is very low viscous, the moving surfaces will come in contact and friction will increase. So, the moderate viscous lubricant is suitable for forcing the moving surfaces apart [4]. Intrinsic viscosity of polymeric additives is in order of $\mathrm{GG}>\mathrm{CMC}>$ PAM, which is the cause of reduction in friction and so on increase in penetration rate.

Percentage improvement with GG, CMC and PAM additives to drilling fluid, considering the tap water alone as base fluid, are $49.7 \%, 48.4 \%$ and $32.9 \%$ increase in rate of penetration (ROP).

\section{CONCLUSION}

From the result of this study we found that the GG and CMC additives with water are better performers in penetration rate improvement compare to polyacrylamide. Guar Gum (GG) is best additive among all drilling fluid used in this study. Use of water soluble polymer additives enhances the drilling performance. For drilling Chunar Sandstone rock GG is better fluid additive.

\section{REFERENCES}

[1] Alsabagh et al, (2014) Investigation of some locally water- soluble natural polymers as circulation loss control agents during oil fields drilling, Egyptian Journal of Petroleum 23, 27-34.

[2] Beste et al. (2010), Rock penetration into cemented carbide drill buttons during rock drilling. Wear 264, 1142-1151.

[3] Bhatnagar et al. (2010), Enhancing diamond drilling performance by the addition of non-ionic polymer to the flushing media, Mining Science and Technology 20, 0400-0405.

[4] Engineering Tribology (2nd Edition). Gwidon W. Stachowiak and Andrew W. Batchelor. Butterworth-Heinemann, Boston, 2001 (740pp).

[5] Iscana et al., (2007), Alteration of permeability by drilling fluid invasion and flow reversal, Journal of Petroleum Science and Engineering 58, 227-244.

[6] Kelessidis et al. (2011), Use of Carbopol 980 and Carboxy methyl cellulose polymers as rheology modifiers of sodium- bentonite water dispersions Applied Clay Science 54, 63-69.

[7] Luiz F.P. Franca (2011), Abit-rock interaction model for rotarypercussive drilling, International journal of Rock Mechanics \& Mining Sciences 48,827-835.

[8] Pathak K. (2010) Introduction of drilling technology, Department of Mining Engineering, IITKGP [intinno.iitkgp.ernet.incourses1192wfiles237159].

[9] Pereza et al. (2004), Non-Newtonian annular vertical flow of sand suspensions in aqueous solutions of guar gum, Journal of Petroleum Science and Engineering 44, 317- 331.

[10] Rao et al. (2002), Laboratory investigation rotary diamond drilling, Geotechnical and Geological Engineering 20, 1-16.

[11] Yadav Upendra Singh and Mahto Vikas (2013), Rheological study of partially hydrolyzed polyacrylamidehexamine- pyrocatechol gel system, International Journal of Industrial Chemistry. 